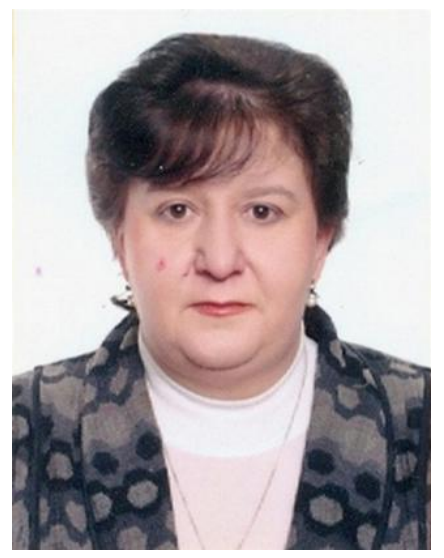

\section{Оксана Романюк,}

старший викладач кафедри іноземних мов і міжкультурної комунікації, Київський національний економічний університет імені Вадима Гетьмана (м. Київ, Україна)

\author{
Oksana Romaniuk, \\ Senior Lecturer, Department of Foreign Languages \\ and Intercultural Communication, Kyiv National \\ Economic University \\ named after Vadym Hetman \\ (Kyiv, Ukraine) \\ oksanaromaniuk75@gmail.com
}

\title{
СТРУКТУРНО-ФУНКЦІОНАЛЬНА МОДЕЛЬ РОЗВИТКУ ПЕДАГОГІЧНОЇ МАЙСТЕРНОСТІ ВИКЛАДАЧІВ ЕКОНОМІЧНИХ ДИСЦИПЛІН В УМОВАХ МАГІСТРАТУРИ
}

Анотація. У статті представлена структурно-функціональна модель розвитку педагогічної майстерності викладачів економічних дисциплін в умовах магістратури та здійснено ії теоретичне обґрунтування, доведена доцільність її використання. Проаналізовано взаємопов'язані між собою блоки запропонованої моделі, а саме теоретичний, змістовопроцесуальний та результативний. Представлено компоненти, критерії та рівні педагогічної майстерності.

У статті визначені такі підходи до розвитку педагогічної майстерності викладачів економічних дисциплін в умовах магістратури, як компетентнісний, психодидактичний, діяльнісний та інноваційний; охарактеризовані принципи, яких необхідно дотримуватися в процесі розвитку педагогічної майстерності викладачів економічних дисциплін в умовах магістратури, а саме професійної спрямованості, мотиваційного спрямування, суб'єктності, пріоритету активних методів навчання та інтерактивних технологій, опори на самостійну роботу студентів. На думку автора впровадження запропонованої структурно-функціональної моделі розвитку педагогічної майстерності в умовах магістратури дає можливість сформувати педагогічну компетентність викладачів економічних дисциплін, що є інтеграцією теоретичних знань, практичних умінь і важливих для викладача особистих якостей.

Ключові слова: структурно-функціональна модель, педагогічна майстерність, викладач економічних дисциплін, магістратура, педагогічна компетентність.

\section{STRUCTURAL AND FUNCTIONAL MODEL OF DEVELOPING PEDAGOGICAL SKILLS OF TEACHERS OF ECONOMICS IN MASTER'S DEGREE PROGRAMMES}

Abstract. The article presents a structural and functional model of developing pedagogical skills of economics teachers in Master's degree programmes. The model has been theoretically substantiated and the advantages of introducing it into Master's degree programmes have been proved. The author analyses each of the three units of the suggested model, namely theoretical issues, procedure in content, results. There have been presented components, criteria and levels of pedagogical skills. The article defines such approaches to developing pedagogical skills of economics teachers in Master's degree programmes as the competence approach, the psychodidactic approach, the action oriented approach, the innovative approach; characterizes principles that are necessary to observe in the process of developing pedagogical skills of economics teachers in Master's degree programmes, namely the principle of professional orientation; the principle of motivational orientation; the principle of subjectivity; the principle of giving priority to active learning methods and interactive technologies; the principle of independent learning. The author expresses the opinion that implementing the suggested structural and functional model of developing pedagogical skills in Master's programmes makes it possible to form the pedagogical competence of economics teachers, which is the integration of theoretical knowledge, practical skills and personal characteristics that are necessary for a teacher. The author sees good prospects for further research which consists in developing a didactic and methodological base for prospective teachers to improve their pedagogical skills by making use of innovative educational technologies as well as in investigating the impact of the suggested model on the results of developing the pedagogical skills of economics teachers in Master's degree programmes.

Keywords: structural and functional model, pedagogical skills, economics teacher, Master's degree programmes, pedagogical competence. 


\section{ВСТУП}

Постановка проблеми. Інтеграція України у світовий освітній простір вимагає постійного вдосконалення національної системи освіти, пошуку дієвих шляхів підвищення якості надання освітніх послуг, розвитку педагогічної майстерності викладачів, апробації та впровадження інноваційних педагогічних систем, реального забезпечення можливостей і свободи вибору в освіті, оновлення змісту освіти й організації її відповідно до світових тенденцій, забезпечення безперервності освіти. Перехід закладів вищої освіти України до нової освітньої парадигми, входження до європейського освітнього простору посилює вимоги до фахової педагогічної компетентності викладачів закладів вищої освіти. Сучасний викладач повинен мати необхідні якості та володіти фаховими знаннями, бути знайомим 3 сучасними досягненнями в науці, вільно орієнтуватися в інформаційних потоках, бути готовим до постійного розвитку своєї педагогічної майстерності.

Розробка проблеми педагогічної майстерності грунтується на наукових положеннях І. Зязюна, М. Солдатенка, Н. Тарасевич, Л. Хомич та інших авторів. Питання розвитку педагогічної майстерності викладачів закладів вищої освіти вивчалися С. Батищевим, Т. Ломакіною, Ш. Соматуловою та іншими науковцями. Значну увагу в дослідженнях згаданих науковців надано висвітленню психолого-педагогічних умов взаємодії суб'єктів у освітньому процесі, а також особливостей розвитку пізнавальної діяльності майбутніх викладачів. Аналіз світового досвіду розвитку педагогічної майстерності висвітлено в науковому доробку О. Лавріненка, Л. Лопуховської, А. Паринова та інших. Проте, незважаючи на інтерес науковців до питань розвитку педагогічної майстерності в умовах переходу української системи вищої освіти до європейського освітнього простору, проблема розвитку педагогічної майстерності викладачів економічних дисциплін у сучасних закладах вищої освіти цілісно не розкрита.

МЕТА І ЗАВДАННЯ ДОСЛІДЖЕННЯ.

Метою статті $€$ характеристика структурно-функціональної моделі розвитку педагогічної майстерності викладачів економічних дисциплін в умовах магістратури.

МЕТОДИ ДОСЛІДЖЕННЯ: для досягнення поставленої мети використано метод моделювання, який є за своєю суттю інтегративним, оскільки дає нам можливість поєднати в педагогічному дослідженні процесу розвитку педагогічної майстерності викладачів економічних дисциплін емпіричне та теоретичне, тобто експеримент 3 побудовою логічних конструкцій.

\section{РЕЗУЛЬТАТИ ДОСЛІДЖЕННЯ}

Моделювання виступає однією з основних категорій теорії пізнання, оскільки на ньому базується будь-який метод наукового дослідження - як теоретичний (у якому використовуються різного роду знакові, абстрактні моделі), так і експериментальний (у якому використовуються предметні моделі) (М. Солдатенко,2007, с. 828).

А. Дахін, досліджуючи питання моделювання компетентності учасників освітнього процесу, визначає модель як штучно створений об'єкт у вигляді схеми, фізичних конструкцій, знакових фрорм, формул, який, будучи схожим на досліджуваний об'єкт (чи явище), відображає і відтворює в більш простому вигляді структуру, властивості, взаємозв'язки і відносини між елементами цього об'єкта (А. Дахін, 2012, с. 24). У словнику професійної освіти знаходимо схоже визначення моделі як зразка, примірника чого-небудь; зменшеного відтворення якогось механізму; типу, марки, зразка конструкції; схеми для пояснення якогось явища або процесу (С. Гончаренко, І. Зязюн\&Н.Ничкало, 2000, с. 195).

У сучасній науці все більшої уваги отримують структурні та функціональні моделі. Структурна модель імітує внутрішню організацію оригіналу. Оскільки структура - це спосіб внутрішньої організації елементів об'єкта, вона є однією з найсуттєвіших сторін будь-якої речі. Без розкриття структури неможливе пізнання внутрішньої природи, сутності об'єктів. Під функціональною моделлю розуміють таку модель, яка імітує спосіб поведінки (функцію) оригіналу (Л. Султанова, 2018, с. 247).

У реальному процесі дослідження окремі типи у чистому вигляді можна зустріти досить рідко, Частіше використовуються змішані моделі. Саме до такого типу належить запропонована структурно-фрунціональна модель розвитку педагогічної майстерності викладачів економічних дисциплін в умовах магістратури. Вибір нами структурнофункціональної моделі зумовлений тим, що процес розвитку педагогічної майстерності викладачів економічних дисциплін є складовою динамічної системи, яка функціонує в таких взаємопов'язаних аспектах, як суспільний та особистісний. Кожний з компонентів може розглядатися як складова частина іншої системи більш високого чи нижчого рівня. Оскільки педагогічна майстерність викладачів економічних дисциплін характеризує професійну діяльність людини, її розвиток має прямий вплив на практичну, теоретичну, колективну й індивідуальну діяльність.

Розглянемо розроблену нами з метою створення системи розвитку педагогічної майстерності в умовах магістратури закладів вищої освіти, ґрунтуючись на здійсненому нами аналізі теорії і практики розвитку педагогічної майстерності викладача, структурно-функціональну модель розвитку педагогічної майстерності викладачів економічних дисциплін в умовах магістратури. У моделі забезпечується єдність мети, компонентів педагогічної майстерності, принципів, змісту, форм, методів розвитку педагогічної майстерності викладачів економічних дисциплін у магістратурі, критеріїв та рівнів її сформованості.

Метою розробленої моделі є розвиток педагогічної майстерності викладачів економічних дисциплін в умовах магістратури. Відповідно, завданнями є вивчення основ педагогічної майстерності; обґрунтування структурних 
компонентів педагогічної майстерності студентів магістратури закладу вищої економічної освіти; формування готовності до педагогічної, дослідницької, організаційної діяльності.

Нами обрано три основні блоки: теоретичний, змістово-процесуальний та результативний. Охарактеризуємо кожний з них. Перший блок, теоретичний, спрямований на обґрунтування наукових підходів і принципів розвитку педагогічної майстерності викладачів економічних дисциплін в умовах магістратури. Важливими домінуючими чинниками, які вплинули на проектування нашої моделі, $є$ теоретичні засади розвитку педагогічної майстерності. Теоретичний блок нашої моделі передбачає врахування вихідних теоретико-методологічних положень, які включають компетентнісний, діяльнісний, психодидактичний та інноваційний підходи.

Врахування компетентнісного підходу в процесі розвитку педагогічної майстерності викладачів економічних дисциплін в умовах магістратури забезпечує розвиток і вдосконалення таких важливих для майбутньої педагогічної діяльності якостей, як моральні, ціннісні, самостійності, прагнення саморозвитку й самовдосконалення, готовність до рефрлексії.

Діяльнісний підхід спрямований на формування активності майбутніх викладачів економічних дисциплін, що сприяє зростанню самостійності, творчості, впевненості в своїх можливостях, розвитку їхньої педагогічної майстерності. Погоджуємось з Н. Оверко у тому, що реалізація діяльнісного підходу до розвитку педагогічної майстерності сприяє формуванню спрямованості особистості, її суб’єктивного досвіду, вдосконаленню педагогічної техніки, саморегуляції діяльності (Н. Оверко, 2016, с. 132).

Процес розвитку педагогічної майстерності викладачів економічних дисциплін в умовах магістратури $\epsilon$, безумовно, складною психодидактичною системою, тому вивчення теоретико-педагогічних та психологічних засад реалізації освітнього процесу, вочевидь, потребує застосування психодидактичного підходу.

Сучасні тенденції в освіті висувають нові вимоги залучення студентів магістратури до проектування освітнього процесу. Це зумовлює потребу в його організації з урахуванням індивідуальних потреб і можливостей. Постає завдання виявити у майбутнього викладача потребу в усвідомленому навчанні. Проте, не кожний майбутній викладач має практичне розуміння того, що йому необхідно для подальшого зростання, професійної самореалізації та розвитку педагогічної майстерності. Оскільки готовність розвиватися, як природну потребу, неможливо надати ззовні, її слід формувати, впроваджуючи інноваційний підхід, залучаючи магістрантів-майбутніх викладачів до більш ефективних рольових моделей, планування своєї кар'єри, проводячи експерименти, які дають змогу оцінити різницю між існуючим станом і бажаним чи необхідним рівнем.

Оскільки принципи визначають стратегію і тактику практичної діяльності викладачів, характер їх творчої взаємодії в освітньому процесі, у запропонованій нами моделі визначено необхідність дотримання у процесі розвитку педагогічної майстерності викладачів економічних дисциплін в умовах магістратури таких принципів: професійної спрямованості, мотиваційного спрямування, суб'єктності, пріоритету активних методів навчання і інтерактивних технологій, опори на самостійну роботу студентів, рефлективності.

Принцип професійної спрямованості ґрунтується на необхідності фундаментальної підготовки викладачів економічних дисциплін, яка забезпечує їх фаховими знаннями, оскільки викладач, який не має належної фундаментальної підготовки не може орієнтуватися в умовах, які об'єктивно постійно змінюються. За таких умов втрачається і компетентність. Одним із способів вираження цього принципу є поєднання загальнонаукової та методичної складових структури дисциплін економічного циклу. Комплекс економічних дисциплін повинен надати майбутньому викладачу, з одного боку, сучасне наукове тлумачення всіх основних понять і фактів відповідної дисципліни, досить широкий світогляд, i, з іншого боку, знання методів навчання цих дисциплін. Таким чином, під час обрання методів навчання ми надаємо перевагу тим методам, які будуть використовуватися майбутнім викладачем. Принцип професійної спрямованості також полягає у тому, щоб усі дисципліни фундаментальної підготовки сприяли надбанню студентами навичок педагогічної діяльності, оскільки освітня діяльність є провідною у закладах вищої освіти.

В основу педагогічного принципу мотиваційного спрямування покладено розуміння соціальної обумовленості потреб і діяльності людини. Принцип мотиваційного спрямування передбачає проникнення в сутність ставлення майбутніх викладачів економічних дисциплін до розвитку педагогічної майстерності, створення в умовах магістратури закладу вищої економічної освіти умов для виникнення внутрішніх спонукань до розвитку педагогічної майстерності. Цей принцип полягає у виділенні та зіставленні, з одного боку, системи стимулів, з іншого - системи мотивів і потреб, на задоволення яких спрямовані ці стимули (Н. Рожкова, 2001, с. 35).

Принцип суб'єктності визнає за особистістю прав на унікальність, внутрішню свободу, активність та духовність, що Ґрунтується на врахуванні інтересів освітнього процесу, пріоритеті особистісно-орієнтованих технологій, передбачає таку спрямованість процесу розвитку педагогічної майстерності викладачів економічних дисциплін в умовах магістратури, яка переносить акценти зі знань, умінь і навичок на особистісний розвиток, забезпечує фундаментальність процесу розвитку педагогічної майстерності, який складається з розробки власної концепції викладання економічних дисциплін, оволодіння психолого-педагогічними технологіями та технологіями управління, прояву творчості у педагогічній діяльності.

Одним з найважливіших напрямів розвитку педагогічної майстерності викладачів економічних дисциплін і обов'язковою умовою ефективної реалізації компетентнісного підходу є впровадження активних методів у освітній процес закладів вищої економічної освіти. Принцип пріоритету активних методів навчання і 
інтерактивних технологій передбачає необхідність застосування нових освітніх технологій та фрорм освітньої діяльності. Перш за все це необхідність переходу від інформаційних методів і форм навчання до активних, переорієнтація від знаннєвого до діяльнісного підходу, пошук можливостей поєднання теоретичних знань студентів 3 їхніми практичними потребами (Л. Наумов, 1986, с. 35).

Реалізація принципу опори на самостійну роботу є можливою за умов оволодіння майбутніми викладачами економічних дисциплін здатністю самостійно розробляти стратегію і тактику виконання завдань, пов'язаних 3 освітньою діяльністю, знаходити необхідну професійну інформацію та оперувати нею у зв'язку з розв'язанням теоретичних і практичних проблем, отримувати нові знання, необхідні для досягнення освітніх цілей, шукати нові засоби вирішення освітніх завдань, формулювати завдання щодо саморозвитку і визначати шляхи їх реалізації.

У процесі розвитку педагогічної майстерності викладачів економічних дисциплін велике значення має рефлексія. Педагогічна наука презентує рефлексію як самоаналіз діяльності та її результатів. Принцип рефлективності має за мету згадати й усвідомити цілі діяльності та процес ії проведення (способи, проблеми, шляхи їх розв'язання), порівняти й зіставити отримані результати з тим, що планувалося та відкоригувати цілі

й напрями подальшої діяльності.

Побудована на ієрархічній системі визначених нами принципів, модель розвитку педагогічної майстерності викладачів економічних дисциплін в умовах магістратури реалізується через функціонування таких компонентів педагогічної майстерності, як мотиваційний, когнітивний, діяльнісний і рефлексивний. Процес розвитку педагогічної майстерності передбачає наявність відповідних педагогічних здібностей і якостей, професійних цінностей і ставлення, професійної компетентності, готовності до творчої діяльності, педагогічної техніки, педагогічної культури.

Змістово-процесуальний блок моделі відображає безпосередньо процес розвитку педагогічної майстерності викладачів економічних дисциплін в умовах магістратури. Це, зокрема, поглиблення теоретичних педагогічних знань, удосконалення практичних умінь i навичок викладачів, оволодіння сучасними досягненнями передового педагогічного досвіду, розвиток творчих здібностей, формування потреби в постійному самовдосконаленні.

Відповідно до змісту розвитку педагогічної майстерності викладачів економічних дисциплін в умовах магістратури пропонуємо використання різних форм: традиційних (лекції, практичні заняття, самостійна робота, контрольні заходи) та інтерактивних (тренінг, дискусія з використанням мультимедійних технологій, робота в малих групах, ділова гра, масові заходи).

Запропоновані нами для розвитку педагогічної майстерності викладачів економічних дисциплін в умовах магістратури традиційні методи (вербальні, наочні, практичні, методи за логікою сприйняття змісту) та інтерактивні методи («мозковий штурм», портфоліо, аналіз конкретних ситуацій, проблемно-пошуковий, метод ігрових технологій, ігрове проектування, презентації, імітаційні вправи) забезпечують фрормування і вдосконалення власного стилю викладання, методику викладання економічних дисциплін.

Динаміку розвитку педагогічної майстерності викладачів економічних дисциплін в умовах магістратури дозволяє визначити і відобразити результативний блок розробленої нами моделі, який передбачає: характеристику компонентів педагогічної майстерності (мотиваційний, когнітивний, діяльнісний і рефлексивний); критеріїв оцінювання рівнів сформованості педагогічної майстерності викладачів економічних дисциплін (мотивація до професійної педагогічної діяльності; загальнопедагогічна підготовленість; здатність до професійної педагогічної діяльності; професійно-особистісна готовність) та рівнів педагогічної майстерності майбутніх викладачів економічних дисциплін (базовий, достатній, високий), які нам дозволять зіставити прогнозовані та отримані результати діагностики та коригування цього процесу.

\section{ВИСНОВКИ ТА ПЕРСПЕКТИВИ ПОДАЛЬШИХ ДОСЛІДЖЕНЬ}

Обґрунтована і розроблена нами структурно-функціональна модель розвитку педагогічної майстерності викладачів економічних дисциплін в умовах магістратури включає визначення мети, теоретичну частину, змістовопроцесуальний блок, а також механізм зворотнього зв'язку, відображений у результативному блоці. Структура моделі ґрунтується на дотриманні логіки досліджуваного процесу: від наявного вихідного стану сформованості основ педагогічної майстерності до цілеспрямованого поступового досягнення майбутніми викладачами більш високого рівня педагогічної майстерності, тому дає можливість експериментально перевірити ефективність розробленого нами змісту, запропонованих форм і методів розвитку педагогічної майстерності викладачів економічних дисциплін в умовах магістратури. Передбачуване нами зростання рівня педагогічної майстерності викладачів економічних дисциплін мотивуватиме їх до подальшого успіху, розширення професійного світогляду, розвитку креативності, критичного осмислення організації освітнього процесу в закладах вищої економічної освіти.

Перспективи подальших досліджень полягають у розробці дидактичного й методичного забезпечення розвитку педагогічної майстерності майбутніх викладачів економічних дисциплін з використанням інноваційних освітніх технологій.

\section{СПИСОК ВИКОРИСТАНИХ ДЖЕРЕЛ}

[1] Гончаренко С. У., Зязюн, І. А., Ничкало Н. Г. (Ред.). Професійна освіта: словник: навч. посіб. Київ: Вища школа, 2000.380 с.

[2] Дахин А. Н. Моделирование компетентности участников открытого общего образования. (Автореф. дис. д-р пед. наук). Институт физико-математических и информационно-экономического образования ФГБОУ ВПО Новосибирский государственный педагогический университет, Нижний Новгород. Новосибирск, 2012. 42 с.

[3] Наумов Л. Б. Учебные игры в медицине. Ташкент: Медицина. 1986. 320 с. 
[4] Оверко Н. Я. Розвиток педагогічної майстерності викладачів спеціальних дисциплін професійно-технічних навчальних за-кладів кулінарного профілю у процесі підвищення кваліфікації. (Дис. канд. пед. наук). Вінницький державний педагогічний університет імені Михайла Коцюбинського, Вінниця. 2016. 20 с.

[5] Рожкова Н. Выясняем соотношение стимулов и мотивов. Директор школы. № 9. С. 35-38.

[6] Солдатенко М. М. Теоретико-методологічні основи розвитку самостійної пізнавальної діяльності майбутнього вчителя. (Автореф. дис. д-ра пед. наук). Інститут педагогіки і психології професійної освіти НАПН України, Київ. 2007. 44 с.

[7] Султанова Л. Ю. Теоретичні і методичні засади полікультурної освіти майбутнього викладача вищого педагогічного навчального закладу. (Дис. д-ра пед. наук). Інститут педагогічної освіти і освіти дорослих імені Івана Зязюна НАПН України, Київ. 2018. 31 c.

\section{REFERENCES (TRANSLATED AND TRANSLITERATED)}

[1] Ghoncharenko S. U., Zjazjun, I. A., Nychkalo N. Gh. (Red.). Profesijna osvita: slovnyk (Professional education: vocabulary): navch. posib. Kyjiv: Vyshha shkola, 2000. 380 s. (in Ukrainian)

[2] Dakhyn A. N. Modelyrovanye kompetentnosty uchastnykov otkrytogho obshhegho obrazovanyja (Competency modeling of participants in open general education). (Avtoref. dys. d-r ped.nauk). Ynstytut fyzyko-matematycheskykh y ynformacyonno-ekonomycheskogho obrazovanyja FGhBOU VPO Novosybyrskyj ghosudarstvennyj pedaghoghycheskyj unyversytet, Nyzhnyj Novghorod. Novosybyrsk, 2012.42 s. (in Russian)

[3] Naumov L. B. Uchebnye yghry v medycyne (Educational games in medicine). Tashkent: Medycyna. 1986. 320 s. (in Russian)

[4] Overko N. Ja. Rozvytok pedaghoghichnoji majsternosti vykladachiv specialjnykh dyscyplin profesijno-tekhnichnykh navchaljnykh zakladiv kulinarnogho profilju u procesi pidvyshhennja kvalifikaciji (Development of pedagogical skills of teachers of special disciplines of vocational schools of culinary profile in the process of advanced training). (Dys. kand. ped. nauk). Vinnycjkyj derzhavnyj pedaghoghichnyj universytet imeni Mykhajla Kocjubynsjkogho, Vinnycja. 2016. 20 s. (in Ukrainian)

[5] Rozhkova N. Vyjasnjaem sootnoshenye stymulov y motyvov (Find out the ratio of incentives and motives). Dyrektor shkoly. № 9. S. 3538. (in Russian)

[6] Soldatenko M. M. Teoretyko-metodologhichni osnovy rozvytku samostijnoji piznavaljnoji dijaljnosti majbutnjogho vchytelja (Theoretical and methodological foundations of the development of independent cognitive activity of the future teacher). (Avtoref. dys. d-ra ped. nauk). Instytut pedaghoghiky i psykhologhiji profesijnoji osvity NAPN Ukrajiny, Kyjiv. 2007. 44 s. (in Ukrainian)

[7] Sultanova L. Ju. Teoretychni i metodychni zasady polikuljturnoji osvity majbutnjogho vykladacha vyshhogho pedaghoghichnogho navchaljnogho zakladu. (Theoretical and methodical principles of multicultural education of the future teacher of higher pedagogical educational institution) (Dys. d-ra ped. nauk). Instytut pedaghoghichnoji osvity i osvity doroslykh imeni Ivana Zjazjuna NAPN Ukrajiny, Kyjiv. 2018. 31 s. (in Ukrainian) 